Dutch Journal of Finance and Management, 1:1 (2016), 37

ISSN: 2468-211X

\title{
Procurement and Supply Chain Management in Government Institutions: A Case Study of Select Departments in the Limpopo Province, South Africa \\ Madira R Selomo ${ }^{1}$, Krishna K Govender ${ }^{2 *}$, \\ Regenesys Business School', University of KwaZulu-Natal, SOUTH AFRICA \\ *Correspondence to: govenderkrishna@gmail.com
}

\section{ABSTRACT}

The current state of the South African (SA) government's Supply Chain Management (SCM) is fraught with malpractices which include lack of good governance, fair, equitable, transparent, competitive and cost-effective procurement process. In light of the aforementioned, this paper reports on a study which examined SCM performance, more specifically, procurement management in select provincial government departments in SA. The aim of this exploratory study on which this paper is written, is to determine how procurement planning, execution, control, and monitoring affect SCM performance. Data was collected using self-administered questionnaires which were personally distributed and collected by the primary researcher, from four Limpopo Provincial government departments which were purposively selected. The Statistical Package for Social Sciences (SPSS) was used to analyse the data.

Keywords

procurement,

public procurement, supply chain management,

governance,

Received: 21 April 2016

Accepted: 28 May 2016

Published Online:08 August 16

DOI: $10.20897 /$ lectito.201637

Generally, SCM performance in the various surveyed government departments is effective, although it became evident that the departments experience obstacles during the implementation of SCM processes and procedures. Furthermore, procurement planning is inadequate and needs improvement when the departments procure goods, services or works. Procurement execution was also found wanting, especially with regards to procurement governance.

The results of this study may assist the participating departments to align their SCM and procurement practices to prescribed legislation in order to increase SCM performance, as well as achieve the objectives of good governance in terms of the Green Paper on Public Sector Procurement Reform in South Africa.

\section{INTRODUCTION}

Procurement reforms in the South African (SA) government started in 1995 and were directed at two broad focus areas, namely, the promotion of the principles of good governance and the introduction of a preference system to address certain socio-economic objectives. The procurement reform processes were supported by the introduction of a number of legislative measures, including the adoption of the Public Financial Management Act (PFMA) and the Preferential Procurement Policy Framework Act (PPPFA) (National Treasury, 2003). The PPPFA was endorsed as a result of Section 217 of the Constitution of the Republic of South Africa which (Republic of South Africa 1996) stipulated the need to implement a procurement policy that will provide preference in the allocation of contracts, and prevent unfair discrimination. PPPFA requires that when government assesses contracts, it must take into consideration the preference point system which prescribes functionality, price, and the Reconstruction Development Programme (RDP) goals. The PPPFA was amended by the Department of Trade and Industry (DTI) and the National Treasury, after the approved B-BBEE Codes of Good Practice in 2006, to advance the objectives of the Broad-Based Black Economic Empowerment Act (B-BBEE Act) and its strategy, as these two legislations were not aligned. The alignment led to the amendment of the Preferential Procurement Regulations (PPR) which was effected in 2011 (National Treasury 2011). 
The Constitution of the Republic of South African (108 of 1996 Section 217) states that when an organ of state of the national, provincial and local spheres of government procures goods or services, it must do so in accordance with a system which is fair, equitable, transparent, competitive and cost-effective. However, the practice prior to 2004 was far from the ideal in a sense that procurement and provisioning activities were ruledriven, and value for money was almost always equated to the lowest price tendered; procurement and provisioning activities were not linked to budgetary planning; the bid documentation was not uniform, causing uncertainty to bidders and practitioners; and the Preferential Procurement Policy Framework Act, No 5 of 2000 and its associated regulations were complex and difficult to implement (National Treasury, 2004: 2). The aforementioned led to the approved adoption of a policy strategy to guide uniformity in the Procurement Reform Process in the government by the South African National Cabinet in September 2003. This was done to replace the outdated procurement and provisioning practices across government institutions with Supply Chain Management (SCM) functions that integrate financial management in procurement processes and conform to international best practices (National Treasury, 2004;5;6;11). The SCM which was implemented in 2004, is a tool that government initiated to manage the procurement process to ensure best practices.

In order to achieve effective procurement practices, compliance audit is one of the control measures used to establish and prove adherence to legislation, regulations and policies. Cosserat (2004: 21) states that "a compliance audit involves obtaining and evaluating evidence to determine whether certain operational activities of an entity conform to specified conditions, rules and regulations." According to the Monitoring and Evaluation (M\&E) framework, organizations are required to establish policies and procedures that provide reasonable assurance that their quality controls are relevant, adequate and comply with best practice. The process includes both ongoing consideration and evaluation of the elements of the quality control system (Cosserat, 2004: 27).

The problem is that since the introduction and implementation of SCM, the SA Auditor General's (AGSA) reports for 2012 and 2014 on procurement and contract management indicated that there are many malpractices (AuditorGeneral South Africa 2014). In light of the above, this research focuses on the SCM model with specific reference to supply chain performance within the context of SCM. More specifically, the following objectives guided the research on which this paper is developed, namely, to determine how procurement planning, execution, control and monitoring affects SCM performance in Limpopo Provincial Government Departments; ascertain how effective SCM is in the Limpopo Provincial Government Departments; and establish how institutional factors affects SCM performance. The research was guided by the following hypothesis: SCM performance in Limpopo Provincial Government Departments is not effective.

\section{RESEARCH METHODOLOGY}

The research used a quantitative design to record and investigate aspects of social reality (Bless et al., 2006: 184). Purposive sampling, a non-probability sampling method was considered appropriate for this research. The sample (Table 1) comprised forty-three (43) SCM employees from four (04) governments departments in the Limpopo province in South Africa. The employees included managers, deputy managers and administrative officers. The participants were chosen based on their involvement in the supply chain and accessibility.

Table 1: Population Composition

\begin{tabular}{|c|c|c|c|}
\hline No & Location & Target Population & Percentage \\
\hline 1 & $\begin{array}{c}\text { Limpopo Provincial Treasury (departmental and } \\
\text { transversal department) }\end{array}$ & 11 & $25.6 \%$ \\
\hline 2 & Department of Roads and Transport & 11 & $25.6 \%$ \\
\hline 3 & Department of Sports, Art and Culture & 11 & $25.6 \%$ \\
\hline 4 & Office of the Premier & 10 & $23.3 \%$ \\
\hline & Total & 43 & $\mathbf{1 0 0} \%$ \\
\hline
\end{tabular}


A self-developed questionnaire comprising Likert-type scales and multiple choice questions was used to gather the data, which was analysed using the Statistical Package for Social Sciences (SPSS) Version 22. The Cronbach's alpha coefficient of 0.956 indicated that the research instrument was fairly reliable.

\section{FINDINGS}

The majority (58.1\%) of respondents were female aged 40 years and above, $51 \%$ were graduates, followed by $37.2 \%$ diplomates, and $9.3 \%$ with only a matric or grade 12 education. The majority $(58 \%)$ of respondents also represented junior management, followed by operational staff and middle management. The majority of respondents have 10 and more years of work experience, and most participants (37.2\%) were from acquisition management, followed by demand management (32.6\%); $14 \%$ from demand and acquisition; 4.7\%, from SCM compliance; $7 \%$ in contract management, with a minority $(2.3 \%)$ from inventory and logistics.

\section{PROCUREMENT PLANNING, EXECUTION, MONITORING AND CONTROLLING OF SCM}

With respect to procurement planning, it became evident that the majority of respondents $(53 \%)$ are positive that planning is adequate, while the remaining $(47 \%)$ say that planning is inadequate; however, with regard to procurement execution, an almost equal number of respondents $(51 \%)$ state that it is inadequate. The majority $(65 \%)$ of respondents are positive that monitoring is adequate, while the remaining $35 \%$ says monitoring is not adequate. Moreover, the majority of respondents (56\%) are positive that controlling is adequate. The findings with respect to each specific question pertaining to procurement planning, execution, monitoring and controlling are captured in Tables 2-5.

With respect to procurement planning, it was evident that only $53 \%$ of the respondents fully understand and agree that planning is the deciding point of the need to procure in terms of what, how, where, when and at what cost (Table 2). Furthermore, planning is not being adequately done when procuring goods, services and works, since over $30 \%$ of the respondents indicated that they do not undertake market research, and specifications are not analysed and recommended by the Bid Specification Committee. Moreover, 51\% of respondents state that procurement of goods, services or works is not carried out effectively. This shows that SCM procedures are not adhered to when procuring goods, services or works as driven by rules. Over $40 \%$ do not publish the list of bidders on the departmental website; $16 \%$ of the quotations above R30 000 are not evaluated by Bid Evaluation Committee; $29 \%$ do not publish the awarded bidder on the Government Tender Bulletin; and 52\% do not evaluate suppliers' capability before capturing them in the departmental suppliers' database. The above practices reflect poor governance or lack of implementation of governance principles with regard to procurement by the select government departments.

\section{Table 2: Procurement Planning}

\begin{tabular}{|c|c|c|c|c|c|c|c|c|c|}
\hline$\stackrel{\dot{2}}{\mathbf{Z}}$ & Statement & 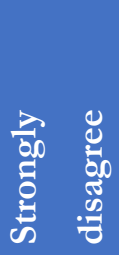 & 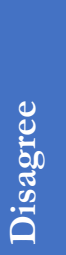 & 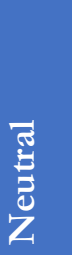 & 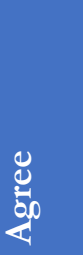 & 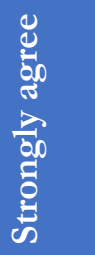 & $\sum_{\Sigma}^{Ð}$ & 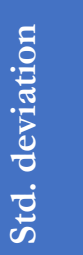 & Z \\
\hline 8 & $\begin{array}{l}\text { The department's procurement process } \\
\text { starts with planning. }\end{array}$ & $4.7 \%$ & 2.3 & 2.3 & 48.8 & 41.9 & 4.21 & .965 & 43 \\
\hline 9 & $\begin{array}{l}\text { The department procures goods, } \\
\text { services and works according to } \\
\text { approved procurement plan as } \\
\text { submitted to the Provincial Treasury. }\end{array}$ & $2.3 \%$ & 0.0 & 9.3 & 41. & 46.5 & 4.30 & .832 & 43 \\
\hline 10 & $\begin{array}{l}\text { The department obtains budget } \\
\text { approval for the required goods, } \\
\text { services or works before procuring. }\end{array}$ & $2.3 \%$ & 4.7 & 4.7 & 25.6 & 62.8 & 4.42 & .957 & 43 \\
\hline 11 & $\begin{array}{c}\text { The department's need is clearly } \\
\text { identified and defined by the requesting } \\
\text { division. }\end{array}$ & $2.3 \%$ & 2.3 & 9.3 & 41.9 & 44.2 & 4.23 & .895 & 43 \\
\hline
\end{tabular}


Dutch Journal of Finance and Management, 1:1 (2016), 37

\begin{tabular}{|c|c|c|c|c|c|c|c|c|c|}
\hline 12 & $\begin{array}{l}\text { The department undertakes market } \\
\text { capability analysis to determine the } \\
\text { procurement method. }\end{array}$ & $2.3 \%$ & 2. & $\begin{array}{c}25 . \\
6\end{array}$ & 39.5 & 30.2 & 3.93 & .936 & 43 \\
\hline 13 & $\begin{array}{l}\text { The specification for procurement of } \\
\text { goods, services or works are analysed } \\
\text { and approved by the appointed } \\
\text { Departmental Bid Specification } \\
\text { Committee. }\end{array}$ & $4.7 \%$ & 0.0 & $\begin{array}{c}11 . \\
6\end{array}$ & 41.9 & $\begin{array}{c}41.9 \\
\%\end{array}$ & 4.16 & .974 & 43 \\
\hline & Mean & \multicolumn{8}{|c|}{4.21} \\
\hline
\end{tabular}

The findings (Table 4) also reveal that $65 \%$ of the respondents 'agree' that monitoring is conducted effectively; however, over $20 \%$ of respondents do not monitor suppliers' performance; $32 \%$ do not receive goods, services or works on time; and 46\% say that SCM does not increase the department's just-in-time service delivery.

Moreover, $56 \%$ of respondents 'agree' that controlling (Table 5) measures are implemented. Over $40 \%$ of the respondents indicated that they do not use electronic suppliers' database; do not have approved turn-around times; are not trained adequately; do not have procurement risk management policy; and do not have segregation of duties and SCM compliance units. However, $65 \%$ of the respondents 'agree' that SCM performance in various Limpopo Provincial Government Departments is effective and efficient.

\section{Table 3: Procurement Execution}

\begin{tabular}{|c|c|c|c|c|c|c|c|c|c|}
\hline$\dot{\dot{Z}}$ & Statement & 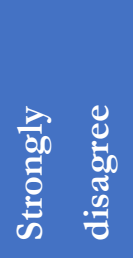 & 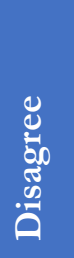 & 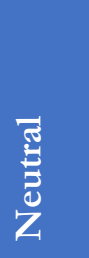 & 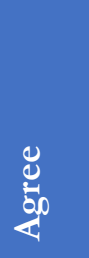 & 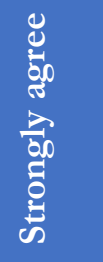 & $\sum_{\Sigma}^{\mathbb{E}}$ & 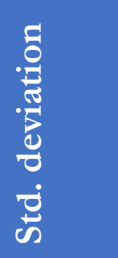 & Z \\
\hline 14 & $\begin{array}{l}\text { The department's bidding documents } \\
\text { are prepared according to the current } \\
\text { regulations; specifications are } \\
\text { accurately defined and neutral with } \\
\text { clear evaluation criteria. }\end{array}$ & $2.3 \%$ & 0.0 & 11.6 & 32.6 & 53.5 & 4.35 & .870 & 43 \\
\hline 15 & $\begin{array}{l}\text { The department use appropriate } \\
\text { procurement methods and award the } \\
\text { contract according to procurement law } \\
\text { and regulations. }\end{array}$ & $2.3 \%$ & 0. & 4.7 & 37.2 & 55.8 & 4.44 & .796 & 43 \\
\hline 16 & $\begin{array}{l}\text { The department procures goods, } \\
\text { services or works according to } \\
\text { approved thresholds without splitting } \\
\text { orders to avoid bid threshold. }\end{array}$ & $4.7 \%$ & 0.0 & 23.3 & 34.9 & 37.2 & 4.00 & 1.024 & 43 \\
\hline 17 & $\begin{array}{c}\text { The department receives a minimum } \\
\text { of three quotations for procurement } \\
\text { transactions equal and less than R500 } \\
000.00\end{array}$ & $4.7 \%$ & 0.0 & 2.3 & 30.2 & 62.8 & 4.47 & .935 & 43 \\
\hline 18 & $\begin{array}{l}\text { The department acquires approval } \\
\text { from the Accounting Officer for any } \\
\text { deviations from the procurement } \\
\text { processes and those deviations are } \\
\text { recorded in the deviation register and } \\
\text { reported to Provincial Treasury and } \\
\text { Auditor General within } 10 \text { working } \\
\text { days. }\end{array}$ & $2.3 \%$ & 0.0 & 14.0 & 37.2 & 46.5 & 4.26 & .875 & 43 \\
\hline 19 & $\begin{array}{l}\text { The department publishes } \\
\text { advertisement of bids in the } \\
\text { departmental website, Government }\end{array}$ & $2.3 \%$ & 2.3 & 14.0 & 32. & 48.8 & 4.23 & .947 & 43 \\
\hline
\end{tabular}


Dutch Journal of Finance and Management, 1:1 (2016), 37

\begin{tabular}{|c|c|c|c|c|c|c|c|c|c|}
\hline & $\begin{array}{l}\text { Tender Bulletin and any other media } \\
\text { for a minimum period of } 21 \text { days. }\end{array}$ & & & & & & & & \\
\hline 20 & $\begin{array}{l}\text { The department close and open bids } \\
\text { on the date stipulated on the bid } \\
\text { document as well as other means } \\
\text { where the bid was published with the } \\
\text { dispatch list acknowledged and signed } \\
\text { by the opening committee. }\end{array}$ & $2.3 \%$ & 2.3 & 7.0 & 34.9 & 53.5 & 4.35 & .897 & 43 \\
\hline 21 & $\begin{array}{l}\text { The department publishes the list of } \\
\text { bidders after closing date in the } \\
\text { departmental website. }\end{array}$ & $4.7 \%$ & $\begin{array}{c}11 . \\
6\end{array}$ & 23.3 & 30.2 & 30.2 & 3.70 & 1.166 & 43 \\
\hline 22 & $\begin{array}{c}\text { The evaluation of bids and quotations } \\
\text { above R30 000.00(evaluation of } \\
\text { administrative documents, technical } \\
\text { evaluation and comparison of price) is } \\
\text { done by the appointed Bid Evaluation } \\
\text { Committee following criteria set in the } \\
\text { bidding document without any } \\
\text { amendment. }\end{array}$ & $4.7 \%$ & 2.3 & 9.3 & 39.5 & 44.2 & 4.16 & 1.022 & 43 \\
\hline 23 & $\begin{array}{l}\text { The appointed Bid Adjudication } \\
\text { Committee considers evaluation report } \\
\text { the bids and quotations above R30 } \\
000.00 \text { then determines the award } \\
\text { contract. }\end{array}$ & $2.3 \%$ & 7.0 & 7.0 & 37.2 & 46.5 & 4.19 & 1.006 & 43 \\
\hline 24 & $\begin{array}{l}\text { The department conducts verification } \\
\text { on PERSAL, SARS, National } \\
\text { Treasury's list of Restricted Suppliers } \\
\text { and register of Tender Defaulters for } \\
\text { the recommended bidders prior } \\
\text { awarding the contract. }\end{array}$ & $2.3 \%$ & 0.0 & 2.3 & 32.6 & 62.8 & 4.53 & .767 & 43 \\
\hline 25 & $\begin{array}{l}\text { The department awards publish the } \\
\text { names of the warded bidder in the } \\
\text { Government Tender Bulletin and } \\
\text { other media by means which the bid } \\
\text { was advertised. }\end{array}$ & $4.7 \%$ & 4.7 & 20.9 & 30.2 & 39.5 & 3.95 & 1.112 & 43 \\
\hline 26 & $\begin{array}{l}\text { The awarded bidder receives } \\
\text { purchasing order and signs the } \\
\text { contract before delivering of goods or } \\
\text { providing services or works. }\end{array}$ & $2.3 \%$ & 0.0 & 11.6 & 32.6 & 53.5 & 4.35 & .870 & 43 \\
\hline 27 & $\begin{array}{l}\text { The department evaluates and } \\
\text { approves suppliers' capability before } \\
\text { capturing in the departmental } \\
\text { suppliers' database. }\end{array}$ & $7.0 \%$ & 7.0 & 37.2 & 27.9 & 20.9 & 3.49 & 1.121 & 43 \\
\hline 28 & $\begin{array}{l}\text { The department create a greater level } \\
\text { of trust among the supply chain } \\
\text { practitioners }\end{array}$ & $2.3 \%$ & 2.3 & 16.3 & 53.5 & 25.6 & 3.98 & .859 & 43 \\
\hline \multirow[t]{2}{*}{29} & $\begin{array}{l}\text { The department has improved } \\
\text { integrated activities across the SCM. }\end{array}$ & $2.3 \%$ & 2.3 & 37.2 & 41.9 & 16.3 & 3.67 & .865 & 43 \\
\hline & Mean & & & & & & 4.08 & & \\
\hline
\end{tabular}


Table 4: Procurement Monitoring

\begin{tabular}{|c|c|c|c|c|c|c|c|c|c|}
\hline$\dot{\mathbf{Z}}$ & Statement & 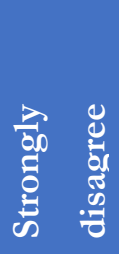 & 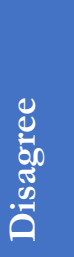 & 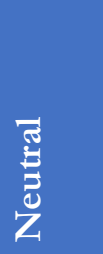 & $\sum_{\substack{4 \\
4}}^{8}$ & 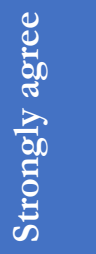 & $\stackrel{\S}{\Sigma}$ & 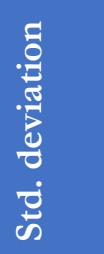 & $\mathbf{Z}$ \\
\hline 30 & $\begin{array}{l}\text { SCM increases the department's Just- } \\
\text { in-Time capabilities. }\end{array}$ & $4.7 \%$ & 0.0 & 41.9 & 34.9 & 18.6 & 3.63 & .952 & 43 \\
\hline 31 & $\begin{array}{l}\text { The department improved on-time } \\
\text { delivery of goods, services or works } \\
\text { from the appointed company. }\end{array}$ & $2.3 \%$ & 2.3 & 27.9 & 51.2 & 16.3 & 3.77 & .841 & 43 \\
\hline 32 & $\begin{array}{l}\text { The department monitors suppliers' } \\
\text { performance as per agreed terms and } \\
\text { conditions. }\end{array}$ & $4.7 \%$ & 0.0 & 25.6 & 51.2 & 18.6 & 3.79 & .914 & 43 \\
\hline 33 & $\begin{array}{l}\text { The SCM division communicates } \\
\text { with end-user of the good, services } \\
\text { or works to get feedback on the } \\
\text { quality of goods supplied or services } \\
\text { rendered or works performed. }\end{array}$ & $4.7 \%$ & 2.3 & 20.9 & 55.8 & 16.3 & 3.77 & .922 & 43 \\
\hline 34 & $\begin{array}{l}\text { The department has updated } \\
\text { procurement report and submitted to } \\
\text { Provincial Treasury as required. }\end{array}$ & $4.7 \%$ & 0.0 & 11.6 & 39.5 & 53.5 & 4.19 & .982 & 43 \\
\hline \multirow[t]{2}{*}{35} & $\begin{array}{l}\text { The department has updated } \\
\text { progress report of all procurement } \\
\text { transactions }\end{array}$ & $2.3 \%$ & 2.3 & 18.6 & 46.5 & 30.2 & 4.00 & .900 & 43 \\
\hline & Total mean & & & & & & 3.93 & & \\
\hline
\end{tabular}

Table 5: Procurement Controlling

\begin{tabular}{|c|c|c|c|c|c|c|c|c|c|}
\hline$\dot{\mathbf{Z}}$ & Statement & 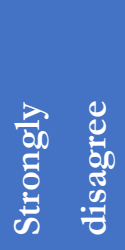 & 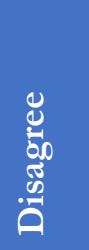 & 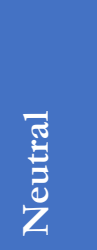 & $\sum_{0}^{\frac{\pi}{4}}$ & 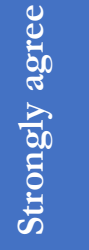 & 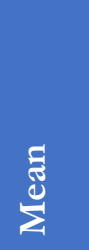 & 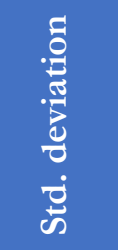 & Z \\
\hline 36 & $\begin{array}{l}\text { The department uses quotation } \\
\text { or tender box for all } \\
\text { procurement of good, services } \\
\text { or works above the value of R30 } \\
\quad 000.00 \text {. }\end{array}$ & $2.3 \%$ & 0.0 & 4.7 & 39.5 & 53.5 & 4.42 & .794 & 43 \\
\hline 37 & $\begin{array}{l}\text { The department uses an } \\
\text { electronic system for suppliers' } \\
\text { database. }\end{array}$ & $11.6 \%$ & 11.6 & 14.0 & 27.9 & 34.9 & 3.63 & 1.381 & 43 \\
\hline 38 & $\begin{array}{l}\text { The department has approved } \\
\text { turn-around times and project } \\
\text { plan for procurement of goods, } \\
\text { services or works. }\end{array}$ & $0.0 \%$ & 4.7 & 37.2 & 44.2 & 14.0 & 3.67 & .778 & 43 \\
\hline 39 & $\begin{array}{l}\text { The department has approved } \\
\text { financial delegations. }\end{array}$ & $2.3 \%$ & 0.0 & $9.3 \%$ & 41.9 & 46.5 & 4.30 & .832 & 43 \\
\hline 40 & $\begin{array}{l}\text { The department segregates } \\
\text { procurement duties. }\end{array}$ & $4.7 \%$ & 2.3 & 16.3 & 41.9 & 34.9 & 4.00 & 1.024 & 43 \\
\hline
\end{tabular}


Dutch Journal of Finance and Management, 1:1 (2016), 37

\begin{tabular}{|c|c|c|c|c|c|c|c|c|c|}
\hline 41 & $\begin{array}{l}\text { The department has clear and } \\
\text { safe record keeping for all } \\
\text { procurement transactions. }\end{array}$ & $2.3 \%$ & 0.0 & 20.9 & 46.5 & 30.2 & 4.02 & .859 & 43 \\
\hline 42 & $\begin{array}{l}\text { The department trains all staff } \\
\text { involved in procurement } \\
\text { activities to identify } \\
\text { procurement fraud and risks as } \\
\text { well as any SCM related. }\end{array}$ & $2.3 \%$ & 4.7 & 32.6 & 32.6 & 27.9 & 3.79 & .989 & 43 \\
\hline 43 & $\begin{array}{l}\text { The department communicates } \\
\text { new development in SCM } \\
\text { Instruction, laws and regulations } \\
\text { to all staff involved in } \\
\text { procurement activities. }\end{array}$ & $2.3 \%$ & 2.3 & 23.3 & 34.9 & 37.2 & 4.02 & .963 & 43 \\
\hline 44 & $\begin{array}{l}\text { The department has an } \\
\text { approved procurement } \\
\text { procedure manual. }\end{array}$ & $4.7 \%$ & 2.3 & 30.2 & 34.9 & 27.9 & 3.79 & 1.036 & 43 \\
\hline 45 & $\begin{array}{l}\text { The department has an } \\
\text { approved SCM policy. }\end{array}$ & $4.7 \%$ & 2.3 & 14.0 & 41.9 & 37.2 & 4.05 & 1.022 & 43 \\
\hline 46 & $\begin{array}{l}\text { The department has an } \\
\text { approved Procurement Risk } \\
\text { Management Policy. }\end{array}$ & $4.7 \%$ & 2.3 & 37.2 & 37.2 & 18.6 & 3.63 & .976 & 43 \\
\hline 47 & $\begin{array}{l}\text { The department has efficient } \\
\text { and forceful demand and } \\
\text { acquisition structures to support } \\
\text { SCM activities. }\end{array}$ & $4.7 \%$ & 9.3 & 20.9 & 32.6 & 32.6 & 3.79 & 1.146 & 43 \\
\hline 48 & $\begin{array}{l}\text { The department has an effective } \\
\text { compliance office that monitors } \\
\text { SCM performance and } \\
\text { compliant to enhance success. }\end{array}$ & $7.0 \%$ & 7.0 & 25.6 & 41.9 & 18.6 & 3.58 & 1.096 & 43 \\
\hline \multirow[t]{2}{*}{49} & $\begin{array}{l}\text { SCM practitioner has signed a } \\
\text { code of conduct for SCM } \\
\text { practitioner. }\end{array}$ & $2.3 \%$ & 2.3 & 4.7 & 41.9 & 48.8 & 4.33 & .865 & 43 \\
\hline & Mean & & & & & & 3.93 & & \\
\hline
\end{tabular}

Table 6 reflects the factors impacting SCM in the various government departments surveyed. The major factors highlighted which obstruct the effectiveness of SCM are late submission of requests to procure by end-users; nonresponsive by suppliers on request to quote; and lack of suitable suppliers on departmental suppliers database.

Table 6: Factors Impacting SCM

\begin{tabular}{|c|c|c|c|c|c|c|c|c|c|}
\hline$\dot{\mathrm{Z}}$ & Statement & 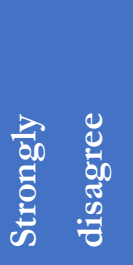 & 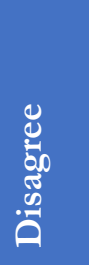 & 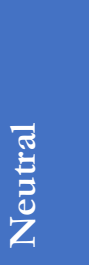 & 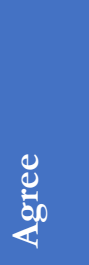 & 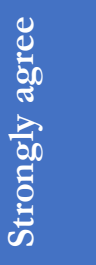 & $\stackrel{\Xi}{\Sigma}$ & 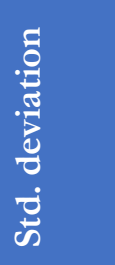 & Z \\
\hline 50 & $\begin{array}{l}\text { Lack of a refined information } \\
\text { system for information sharing } \\
\text { among supply chain } \\
\text { practitioners. }\end{array}$ & $4.7 \%$ & 11. & 32. & 41. & 9.3 & 3.40 & .979 & 43 \\
\hline 51 & $\begin{array}{l}\text { Lack of trust and cooperation } \\
\text { among supply chain } \\
\text { practitioners. }\end{array}$ & $11.6 \%$ & 14.0 & 39.5 & 20.9 & 14.0 & 3.12 & 1.179 & 43 \\
\hline 52 & $\begin{array}{l}\text { Last minutes submission of } \\
\text { request to procure by end-user. }\end{array}$ & $4.7 \%$ & 4.7 & 14.0 & 39.5 & 37.2 & 4.00 & 1.069 & 43 \\
\hline
\end{tabular}


Dutch Journal of Finance and Management, 1:1 (2016), 37

\begin{tabular}{|l|l|l|l|l|l|l|l|l|l|}
\hline 53 & $\begin{array}{l}\text { Suppliers' geographical distance } \\
\text { from the department's facilities. }\end{array}$ & $7.0 \%$ & 9.3 & 32.6 & 32.6 & 18.6 & 3.47 & 1.120 & 43 \\
\hline 54 & $\begin{array}{l}\text { Non-responsive on the request } \\
\text { to quote by invited suppliers. }\end{array}$ & $7.0 \%$ & 0.0 & 30.2 & 34.9 & 27.9 & 3.77 & 1.088 & 43 \\
\hline 55 & $\begin{array}{l}\text { Lack of suitable suppliers on the } \\
\text { departmental suppliers } \\
\text { database. }\end{array}$ & $11.6 \%$ & 7.0 & 23.3 & 34.9 & 23.3 & 3.51 & 1.261 & 43 \\
\hline & Mean & & & & & & $\mathbf{3 . 5 4}$ & & \\
\hline
\end{tabular}

Table 7 provides the $\mathrm{R}, \mathrm{R}^{2}$, adjusted $\mathrm{R}^{2}$, and the standard error of the estimate used to determine how well a regression fits the data. The $\mathrm{R}$ column represents the value of $\mathrm{R}$, the multiple correlation coefficient, which is considered a measure of the quality of the prediction of the dependent variable which in this case is SCM performance. The value of 0.494 indicates the level of prediction. The $\mathrm{R}^{2}$ value $(0.244)$ which is the coefficient of determination indicates that independent variables explain $24.4 \%$ of the variability of dependent variable; which implies that $75.6 \%$ of variations is explained by other factors not reflected in this model.

Table 7 Model Summary

\begin{tabular}{|l|l|l|l|l|}
\hline Model & $\mathrm{R}$ & R Square & Adjusted R Square & Std. Error of the Estimate \\
\hline 1 & $.494^{\mathrm{a}}$ & .244 & .165 & 4.320 \\
\hline
\end{tabular}

a. Predictors: planning, execution, monitoring, controlling

Table 8 shows that the independent variables (planning, execution; monitoring and eventually) statistically predict the dependent variable (SCM performance), $\mathrm{F}(4,38)=3.069$ and $\mathrm{p}<0.05=0.028$.

Table 8: ANOVA Results

\begin{tabular}{|c|c|c|c|c|c|}
\hline Model & Sum of Squares & Df & Mean Square & F & Sig. \\
\hline \multirow{2}{*}{$\begin{array}{c}\text { Regression } \\
\text { Residual } \\
\text { Total }\end{array}$} & 229.092 & 4 & 57.273 & 3.069 & $.028^{\mathrm{b}}$ \\
\cline { 2 - 6 } & 709.095 & 38 & 18.660 & & \\
\cline { 2 - 6 } & 938.186 & 42 & & & \\
\hline
\end{tabular}

a. Dependent variable: SCM performance

b. Predictors: (constant), planning, execution, monitoring, controlling

c. The general form to predict SCM performance from planning, execution, monitoring and controlling is:

d. Predicted $Y_{\text {SCMperformance }}=\beta_{0}+\beta_{1} X_{\text {planning }}+\beta_{2} X_{\text {Execution }}-\beta_{3} X_{\text {monitoring }}+\beta_{4} X_{\text {controlling }}$

e. Predicted

$Y_{\text {SCMperformunce }}=5.658+0.315 X_{\text {planning }}+0.116 X_{\text {Execution }}-0.182 X_{\text {monitoring }}+0.036 X_{\text {controlling }}$

Table 9: Coefficients ${ }^{\mathrm{a}}$

\begin{tabular}{|c|c|c|c|c|c|c|}
\hline & \multirow[t]{2}{*}{ Model } & \multicolumn{2}{|c|}{ Unstandardized Coefficients } & $\begin{array}{l}\text { Standardized } \\
\text { Coefficients }\end{array}$ & \multirow[t]{2}{*}{$\mathrm{t}$} & \multirow[t]{2}{*}{ Sig. } \\
\hline & & B & Std. Error & Beta & & \\
\hline \multirow[t]{4}{*}{1} & (Constants) & 5.658 & 4.787 & & 1.182 & .245 \\
\hline & Planning & .315 & .219 & .281 & 1.441 & .158 \\
\hline & Execution & .116 & .109 & .280 & 1.061 & .296 \\
\hline & Monitoring & -.182 & .405 & -.120 & -.448 & .656 \\
\hline
\end{tabular}




\begin{tabular}{|c|c|c|c|c|c|}
\hline Controlling & .036 & .186 & .066 & .194 & .847 \\
\hline
\end{tabular}

a. Dependent variable: SCM performance

Table 4 which the unstandardised coefficient indicates how much dependable variable varies with an independent variable when all other independent variables are held constant. It is evident that the unstandardised coefficient, B1, for monitoring is equal to -182 , which implies that when one unit of monitoring increases, SCM performance would decrease by the 0.182 monitoring units. The variables with the positive and highest beta are planning and execution, while controlling is positive with lowest beta; therefore, planning, execution and controlling have positive relationship to SCM performance.

Figure 1 shows the different factors which prevent the effectiveness of SCM in various provincial departments. The mean of the responses is 3.54 and standard deviation is 1.12, based on the Likert-type scale of (5) strongly agree, (4) agree, (3) neutral, (2) disagree and (1) strongly disagree, which imply that the respondents 'agree' that the factors in Figure 1 do indeed prevent the effectiveness of SCM.

\section{Figure 1: Factors which prevent effective SCM}

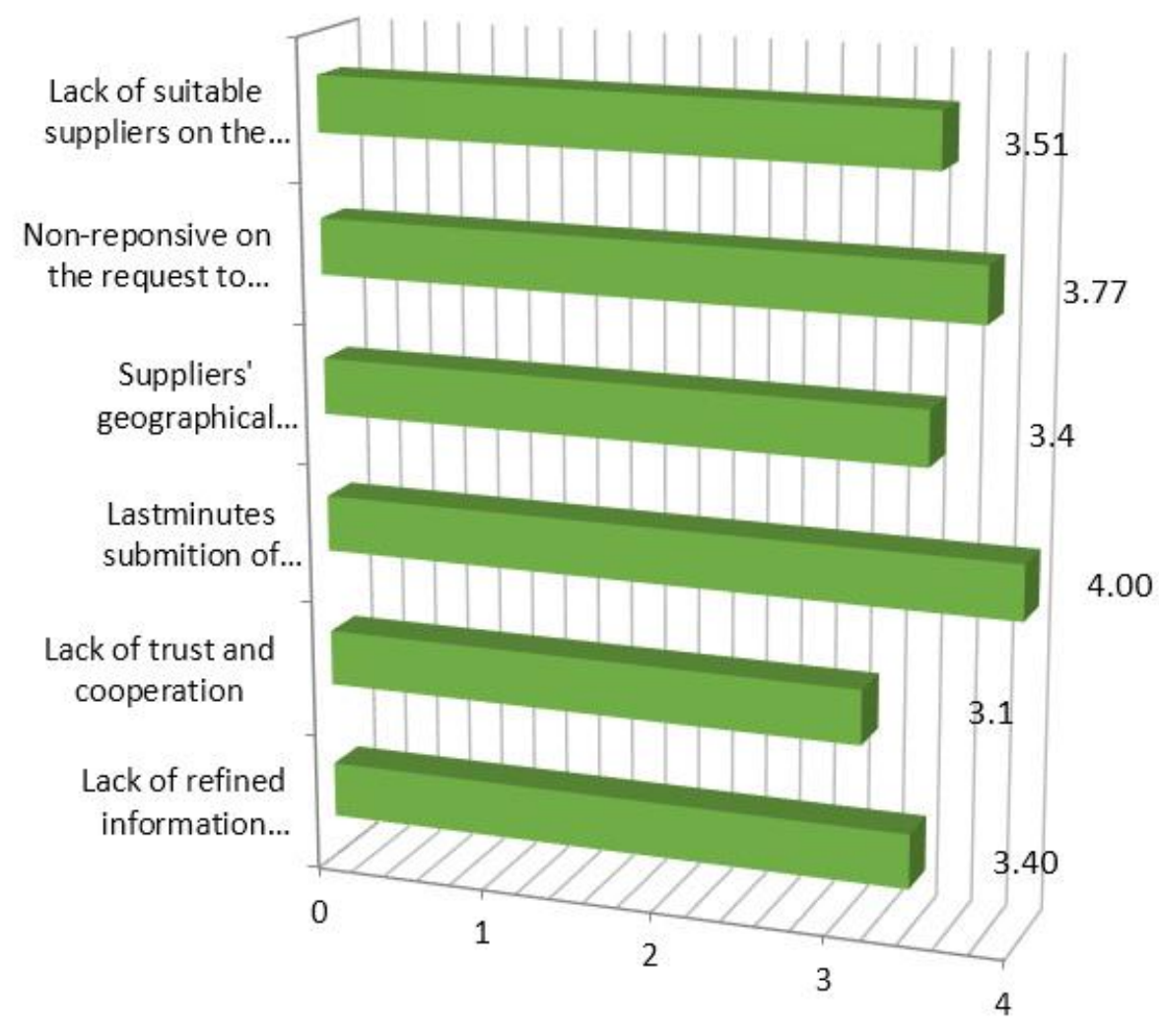

\section{Discussion and Recommendations}

The objectives of the study were to determine how procurement planning, execution, control and monitoring affects SCM performance in Limpopo Provincial Government Department and to establish how institutional factors affects SCM performance in these departments. Vogt, Pienar and de Wit (2006:78); Kumar (2011); Lambert (2001); and CIPS listed the aforementioned aspects as the scope of procurement and supply chain management, which serve to emphasize the need to procure goods, services or works within the expected period and as required by the requesting entity.

The study revealed that generally, SCM performance in various Limpopo Provincial government departments is effective, although the departments experience obstacles during the implementation of SCM processes and procedures. Furthermore, procurement planning is inadequate and needs improvement when the departments procure goods, services or works. Procurement execution is also found wanting, especially with regards to procurement governance. 
The above findings have to be interpreted in the context of national government initiatives to ensure effective SCM, which would eventually impact service delivery to its citizens. The SA government moved from the ruledriven procurement system to SCM to manage public procurement and address the core best practices such as the need for value for money; effective monitoring and reporting; skills development of key procurement personnel; and integrated procurement processes to focus on whole life costs and benefits. According to the Green Paper on Public Sector Procurement Reform in South Africa (Republic of South Africa 1997), the objectives in terms of good governance are to promote effective procurement practices and systems to enable government to timeously deliver quality and quantity of services; achieve continuing improvement in value for money based on whole life cost and quality; enhance the competitiveness of suppliers through the development of world class procurement systems and practices; ensure that control and accountability is maintained through comprehensive auditing; and achieve a uniform procurement system with standardized tendering procedures, policies and contract documentation.

Government procurement in all spheres should transform to best SCM practices in order to improve operations, by adopting philosophies, methods and processes that will make them reach best class level. The approach involves among others, establishment of regulatory mandates, alignment of staff and structure, technology usage, establishment of agreements with key suppliers, engagement of collaborative strategic sourcing, focus on Total Cost Ownership (TCO) not the price, constructive management of contracts, optimised organizational-owned inventory, the stablishment of appropriate levels of control, and minimising risks.

\section{REFERENCES}

Auditor-General South Africa. 2014. PFMA: Consolidated General Report on National and Provincial Audit Outcomes: 2012-13. Pretoria: Government Printers.

Bless, C., Higson-Smith, C. \& Kagee, A. 2006. Fundamentals of Social Research Methods: An African Perspective. Cape Town: Juta and Co. Ltd.

Cosserat, G.W. 2004. 'Modern Auditing'. 2nd ed. England: British Library.

Kumar, B.P. 2011. Supply Chain Management: An Exploring Areas of Management Research. Jayawant Institute of Management Studies, Tathawade, Pune: India.

Lambert, D.M. 2001. Handbook in Transport Volume 2: Chapter 7 of Handbook of Logistics and Supply Chain Management. Elsevier Science Ltd.

Limpopo Provincial Treasury. 2004. Instructions on Supply Chain Management. Pretoria: Government Printers.

Limpopo Provincial Treasury. 2007. Policy on Bid Committee. Pretoria: Government Printers.

National Treasury. 2003. Regulations in terms of the Public Finance Management Act, 1999: Framework for Supply Chain Management. Pretoria: Government Printers.

National Treasury. 2005. Supply Chain Management: A Guide for Accounting Officers and Municipal entities. Pretoria: Government Printers.

National Treasury. 2005. Treasury Regulations for Department, Trading Entity, Constitutional Institutions and Public Entities. Pretoria: Government Printers.

National Treasury. 2006. Code of Conduct for Bid Adjudication Committees. Pretoria: Government Printers.

National Treasury. 2011. Supply Chain Management: Guidelines on the Implementation of Demand Management. Pretoria: Government Printers.

National Treasury. 2011. Implementation Guide: Preferential Procurement Regulations, Pertaining to the PFMA, Act No 5 of 2000. Pretoria: Government Printers.

Republic of South Africa. 2003. Broad-Based Black Economic Empowerment Act. Pretoria: Government Printers. Republic of South Africa. 1999. Public Finance Management Act. Pretoria: Government Printers.

Republic of South Africa. 1996. Constitution of the Republic of South Africa Act. Pretoria: Government Printers. Republic of South Africa. 1997. Green Paper on Public Sector Procurement Reform in South Africa. Government Gazette No. 17928. Pretoria: Government Printers.

Republic of South Africa. 2000. Preferential Procurement Policy Framework Act. Pretoria: Government Printers. Vogt, J.J., Pienaar, W.J. \& de Wit P.W.C. 2006. 'Business Logistics Management: Theory and Practices'. New York: Oxford. 